\title{
On the Significance of Labor Reallocation for European Unemployment: Evidence from a Panel of 15 Countries*
}

\author{
Dimitrios Bakas ${ }^{\mathrm{a}, \mathrm{f}}$ Theodore Panagiotidis ${ }^{\mathrm{b}, \mathrm{f}}$ Gianluigi Pellonic, $\mathrm{d}, \mathrm{e}, \mathrm{f}$ \\ a Nottingham Trent University, UK \\ b University of Macedonia, Greece \\ c University of Bologna, Italy \\ d Wilfrid Laurier University, Canada \\ e Johns Hopkins University, SAIS Bologna Center, Italy \\ $\mathrm{f}$ Rimini Centre for Economic Analysis (RCEA), Italy
}

27 April 2016

\begin{abstract}
We explore the macroeconomic effects of sectoral shifts for 15 European countries. An extensive panel is constructed that allows us the assessment of the impact of labor reallocation on unemployment in the European context. Indexes of labor market turbulence based on alternative sectoral disaggregation are constructed. The effect of labor reallocation on unemployment is found to be positive and significant in all different specifications. This remains robust when we take into account volatility measures in the model.
\end{abstract}

JEL classification: E24, E32, J21, R23, C23

Keywords: labor reallocation, sectoral shifts hypothesis, unemployment, EU

\footnotetext{
* Acknowledgements: We would like to thank Richard Bailey and two anonymous referees for their constructive comments and helpful suggestions. We would also like to thank Karim Abadir and Paolo Giordani for their useful comments and suggestions on earlier versions of this work. All remaining errors are our own.

Bakas: Nottingham Trent University, Nottingham Business School, Burton Street, NG1 4BU, Nottingham, UK,

E-mail: dimitrios.bakas@ntu.ac.uk

Panagiotidis: University of Macedonia, Department of Economics, 156 Egnatia Street, 54006, Thessaloniki, Greece,

E-mail: tpanag@uom.edu.gr (Corresponding Author)

Pelloni: University of Bologna, Department of Economics, Via Anghera 22, 47900, Rimini, Italy,

E-mail: gianluigi.pelloni@unibo.it
} 


\section{INTRODUCTION}

A disparity of adjustments response across the Euro-area labor markets has characterized the Great Recession and the sovereign debt crises (European Central Bank, 2012). Recently this insight about the relative importance of (within) state regional heterogeneity for unemployment has been explored, with different emphasis on sectoral reallocation or regional mobility using country specific dynamic reduced form equation or panel SVAR's (see Dao et al. (2014), Hogrefe and Sachs (2014) and Beyer and Smets (2015) among others). These approaches have provided contradictory results. Hogrefe and Sachs (2014) have shed doubts on the relevance of sectoral reallocations for some of the "troubled economies" of the EU. On the other hand, Dao et al. (2014) and Beyer and Smets (2015) assign a significant, and possibly increasing, importance to both region-specific shocks and reallocation of jobs (and labor) across regions. In the light of recent advances in dynamic panel data modelling, it is the purpose of this paper to extend these previous results by framing the analysis in a heterogeneous panel data model that addresses for cross country interdependence in the EU context.

In this study we examine the effect of labor reallocation on unemployment for European labor markets within a panel framework that takes into account dynamics, parameter heterogeneity and cross sectional dependence. The contribution of the paper is threefold: (i) we build an extensive dataset of 1165 observations for 15 European countries to assess the significance of labor reallocation on unemployment, (ii) we employ recently developed panel methodologies that allows us to take into account characteristics that are endemic to the hypothesis and (iii) we provide evidence that the sectoral reallocation index remains a significant determinant for rising unemployment even when aggregate volatility and expected volatility measures are taken into account.

The rest of the paper is organized as follows. Section II outlines the background literature on the topic, section III discusses the model and estimation methodology and section IV presents the data. The results are discussed in section V and finally, section VI concludes. 


\section{BACKGROUND}

Draghi (2014) has recently reminded us that the heterogeneous picture lying behind the aggregate data reflects highly "different initial conditions such as varying sectoral composition of employment". His analysis is consistent with the ECB report on EU labor markets (European Central Bank, 2012) that stresses the structural nature of European unemployment and the limited power of monetary policy in tackling this issue. Structural reforms are indispensable both at the individual state and the Union level (see also the discussion in De Grauwe (2016)). This view has attracted the attention of researchers who have been trying to substantiate it econometrically from different perspectives.

Hogrefe and Sachs (2014) analyse a subset of EU countries (France, Ireland, Italy, Portugal, Spain) and use a difference specification of Okun's approach (Okun, 1962) to estimate separately error correction models for each country. Their findings show that sectoral reallocations drove Spanish unemployment over the decade 2004-2014, while they are not significantly related to unemployment in France, Ireland and Portugal and are only marginally significant in Italy. The paper presents interesting results but focuses on a limited set of countries and the chosen methodology (Autoregressive Distributed Lagreduced form estimation for each country) does not take into account the potential interdependence between countries.

Dao et al. (2014) and Beyer and Smets (2015) are rooted in the pioneering work of Blanchard and Katz (1992) and use panel VAR's. Their focus is on the importance of labor migration for long run labor markets adjustments in both the US and EU. Dao et al. (2014) estimate a system panel VAR with three state level variables: state-relative employment growth, state-relative log employment rate and state-relative log participation rate for Europe and the USA. By imposing suitable restrictions, they conclude that the long-run effect of a state-specific shock on the state employment has decreased over time. Also the short term response of participation rates to labor demand shocks is found to be larger in Europe compared to the US.

Beyer and Smets's (2015) two-steps estimation procedure is aimed first at decomposing regional variables in three orthogonal components (continental, country, regional) via a multi-level factor model and then at estimating the impact of region-specific and country- 
specific shocks on labor markets via panel VAR's pooled over the relevant subsamples. On the one hand they highlight the differences between the two sides of the Atlantic: in Europe labor mobility is less important for the adjustment mechanism to region-specific labor demand shocks compared to the US. On the other, they detect convergence of the adjustment process as interstate migration in the US (Europe) is falling (increasing).

As Hogrefe and Sachs (2014), we are interested in testing and measuring the impact of inter-sectoral reallocation on unemployment. However, operationally we are closer to Dao et al. (2014) and Beyer and Smets (2015) though their interest is mainly on migration while ours is on unemployment. Given industrial structures differing across EU states, each state would be affected differently by sectoral shocks. If a shock hits unfavourably the demand composition of a specific state the workers affected will become unemployed, drop out of the labor force or migrate to another country. On the other hand aggregate shocks (e.g. shocks linked to ECB monetary policy) will affect all countries and, even if sectors, and so individual countries, respond differently, it is unlikely they will generate much labor mobility across countries. This holds because the probability of finding a job elsewhere would not be much different.

In this paper we focus on labor reallocation and its impact on the unemployment rate vis-a-vis potentially alternative triggering forces. We capture reallocation via a "purged" Lilien's dispersion proxy (Lilien, 1982). Unemployment brought about by labor reallocation could largely reflect the process of "creative destruction" (Shumpeter (1976) and Aghion and Howitt (1992)). Improving the productivity of inputs technological progress, as a determinant of economic growth, would create profit prospects, encourage job creation and destroy outdated jobs. Lilien's index of labor reallocation could reflect this incessant process of job creation and destruction to the extent allowed by its sectoral decomposition (i.e. a relatively thinner sectoral decomposition should in principle be able to encapsulate more of the labor reallocation linked to jobs restructuring). Counteracting the associated potential increase in unemployment via aggregate demand policies and/or implementing other policies aimed at slowing down jobs destruction would obstruct the process of endless restructuring necessary for growth. It is important to separate unemployment generated by adverse aggregate shocks from unemployment linked to "creative destruction". 
We expand previous work by considering also the impact of volatility measures on unemployment as captured by the so called "uncertainty" indexes which measures the economic policy expected volatility (Bloom (2009)). Caggiano et al. (2014) explore the effects of volatility index (VIX) and economic policy uncertainty index (EPU) shocks on unemployment dynamics using a non-linear VAR for the US. They provide evidence of a significant increase of unemployment after a one standard deviation-shock to volatility and uncertainty proxies. Baker at al. (2015) develop a new index of policy-related economic uncertainty and estimate its dynamic relationship to employment. Their results bear out that the policy uncertainty index leads to a significant decline in employment for the US and for a panel of 12 major economies. Choi and Loungani (2015) similarly, explore the role of uncertainty shocks on unemployment dynamics by distinguishing between aggregate and sectoral channels of volatility and comparing their effects on the unemployment rate. They show that the response of unemployment to aggregate uncertainty and sectoral uncertainty is different, and thus, that sectoral uncertainty shocks have more persistent effects for unemployment.

In extending the above mentioned literature, we estimate a reduced form panel equation that takes into account dynamics, parameter heterogeneity and cross sectional dependence according to recent advances in the field. ${ }^{1}$ Finally, given the recent empirical evidence on the significance of economic volatility and uncertainty shocks for unemployment, we also consider an extended specification accounting for the effect of volatility and expected volatility measures.

\section{MODEL AND METHODOLOGY}

We estimate an unemployment reduced form equation of the form used by Mills et al. (1995). Lilien's (1982) original approach focused only on monetary shocks vis-à-vis reallocation shocks, while Mills et al. (1995) allow for a larger set of aggregate covariates thus allowing for a more thorough testing of the sectoral shifts hypothesis. Using pooled time-series-cross-section data for the period 1995Q1-2015Q1 and for 15 European countries

\footnotetext{
${ }^{1}$ See Bakas et al. (2016) for a similar approach for the US and Chudik and Pesaran (2015b) for an extensive survey on heterogeneous panel data models with cross-sectional dependence.
} 
( $N=15$ and $T=81$, results to a total of 1165 observations due to data restrictions and adjustments), we employ a dynamic heterogeneous panel analysis for the equation:

$$
U_{i, t}=\mu_{i}+a_{i} U_{i, t-1}+\beta_{i} \sigma_{i, t}^{p}+\lambda_{i}^{\prime} z_{i, t}+u_{i, t}
$$

where $U_{i, t}$ is unemployment for EU country $i$ at time $t ; \mu_{i}$ denotes a set of countryspecific fixed effects capturing the influence of unobserved state-specific heterogeneity; $\sigma_{i, t}^{p}$ is the index of dispersion; the vector $z_{i, t}$ is a vector of EU country specific control variables among which we include the real GDP growth, $\Delta G D P_{i, t}$; the interest rate growth, $\Delta I R_{i, t}$, its (GARCH) variability, $H_{i, t}$, and the growth rate of government expenditures, $\Delta G_{i, t}$; finally, $u_{i, t}$ is the error term.

The variable $\sigma_{i, t}^{p}$ is the EU country "purged" measure of employment dispersion across sectors. ${ }^{2}$ Letting $N_{j, i, t}$ and $N_{i, t}$ be the employment in sector $j$ in country $i$ at time $t$ for $j=$ $1,2 \ldots, 10$, and aggregate employment in country $i$ at time $t$ respectively, while $N_{j, i, t} / N_{i, t}$ are weights defining by the relative size of each sector in each country, we can measure the "standard" dispersion proxy (Lilien, 1982) for each country $i$ at time $t$ as follows:

$$
\sigma_{i t}=\left[\sum_{j}\left(\mathrm{~N}_{\mathrm{j}, \mathrm{i}, \mathrm{t}} / \mathrm{N}_{\mathrm{i}, \mathrm{t}}\right)\left(\Delta \ln \mathrm{N}_{\mathrm{j}, \mathrm{i}, \mathrm{t}}-\Delta \ln \mathrm{N}_{\mathrm{i}, \mathrm{t}}\right)^{2}\right]^{1 / 2}
$$

We filter out any potential aggregate influences from $\sigma_{i t}$ by regressing it on a vector of aggregate variables $\widetilde{\mathrm{w}}_{\mathrm{t}-\mathrm{k}}:^{3}$

$$
\sigma_{i, t}=\phi_{\mathrm{i}}+\sum_{\mathrm{k}=0}^{\mathrm{q}} \theta \widetilde{\mathrm{w}}_{\mathrm{t}-\mathrm{k}}+\xi_{\mathrm{i}, \mathrm{t}}
$$

The estimated residual, $\widehat{\xi_{1, t}}$, is then the dispersion measure 'purged' of aggregate effects, denoted hereafter as $\sigma_{i, t}^{p} \cdot{ }^{4}$

\footnotetext{
2 The ten sectors are agriculture, industry, construction, trade, information, financial, real estate, professional, public and other sectors as defined in the OECD Quarterly National Accounts database.

${ }^{3}$ In this case we have used the change of interest rate; its GARCH variability and the growth rate of government consumption expenditure for each country (see also the data section).
} 
We assume a multi-factor error structure so as to take into account cross correlation of the disturbances:

$$
u_{i, t}=\sum_{j=1}^{N} \gamma_{i j} f_{j t}+e_{i t}
$$

The $u_{i, t}$ can be decomposed as:

$$
u_{i, t}=f s_{i t}+f w_{i t}
$$

where $f^{s}{ }_{i t}=\sum_{l=1}^{m} \gamma_{i l} f_{l t}$ and $\boldsymbol{f}^{w_{i t}}=\sum_{l=\mathrm{m}+1}^{N} \gamma_{i l} f_{l t}+e_{i t}$ and $m$ is fixed (see Chudik et al. (2011) and Chudik and Pesaran (2015b)).

In Equation (4) $f_{j t}$ is an $m$-dimensional column vector of unobservable common factors capturing cross-sectional dependencies across countries, the $\gamma_{i j}$ are the country specific factor loadings and the idiosyncratic errors $e_{i, t} \sim$ IID across $i$ and $t$. In Equation (5) $f^{s} s_{i t}$ is a vector of a finite number of 'strong' factors (common global shocks to all EU countries) while $f^{w_{i t}}$ contains a vector of an infinite number of 'weak' factors (regional spillover effects across subsets of EU countries) and the idiosyncratic errors. ${ }^{5}$

Alternative approaches are employed to estimate the impact of labor reallocation on unemployment. Both homogeneous and heterogeneous estimators are used to explore the robustness of the effect. We start with the pooled OLS (POLS) as well the fixed effects approach which allows the intercepts to differ across countries (FE and $\mathrm{FE}_{\mathrm{T}}$ ). Next, we move to their extensions proposed by Driscoll and Kraay's (1998) that employ a nonparametric variance-covariance matrix estimation which produces heteroskedasticity and autocorrelation consistent standard errors that remain robust to the presence of generalized forms of spatial and cross-sectional dependence (DK-POLS and DK-FE). Furthermore, given the dynamic specification of Equation (1), we proceed and employ the system GMM estimator of Blundell and Bond (1998) (GMM). To account for the presence

\footnotetext{
4 The potential sensitivity of Lilien's measure to aggregate shocks was pointed out by Abraham and Katz (1986). The "observational equivalence" problem and the purging methodology are discussed in Gallipoli and Pelloni (2013).

5 The cross sectional dependence in our panel data context could be taken into account by employing the Common Correlated Effects (CCE) approach of Pesaran (2006) (see also Chudik et al. (2011) and Chudik and Pesaran (2015b)). The CCE method is appealing since it does not require estimating the unobservable common factors directly. It can account for common factors by including cross-sectional averages of the dependent and explanatory variables (as approximations of the unobserved factors) in the panel regressions.
} 
of cross sectional dependence in the homogeneous modeling we employ the pooled common correlated effects estimator (CCEP and CCEP $)$ suggested by Pesaran (2006).

Given the importance of heterogeneity and cross country interdependence in the EU context, we proceed to the estimation of heterogeneous panel models with cross-sectional dependence; the heterogeneous version of the CCE estimator (CCEMG and CCEMGT) as suggested by Pesaran (2006) and the AMG estimator by Bond and Eberhardt (2009) which allows for parameter heterogeneity and accounts also for cross sectional dependence in the panel. Finally, we implement the recent extension of the Mean Group Common Correlated Effects estimator (dynCCEMG) that is proposed in Chudik and Pesaran (2015a) and permits the inclusion of lagged dependent variables and weakly exogenous regressors in the panel data modeling.

\section{DATA}

We employ quarterly data for an unbalanced panel of 15 European Countries: Austria, Belgium, Denmark, Finland, France, Germany, Greece, Ireland, Italy, Luxembourg, Netherlands, Portugal, Spain, Sweden, United Kingdom, over the period 1995Q1-2015Q1. Table 1 presents the list of countries and their abbreviations. The data for sectoral employment are from the OECD Quarterly National Accounts while the macroeconomics variables used in the analysis were obtained from OECD's Main Economic Indicators and Labour Market statistics databases. The reallocation index is computed for each country using the shares of the available sectoral decomposition of quarterly employment based on the following 10 sectors (see note 2). Using this industrial decomposition, we compute measures of reallocation $\left(\sigma^{p}\right)$ allowing for alternative sectoral disaggregation $(4,5,8,9$ and 10 sectors respectively).

We use the logarithmic form of the unemployment rate as the dependent variable, $U_{i, t}$ $=\ln \left(u n_{i, t}\right)$, where $u n_{i, t}$ is the unemployment rate (in decimal). The macro variables are the real GDP growth, $\Delta G D P_{i, t}=\Delta \ln \left(r g d p_{i, t}\right)$, where $r g d p_{i, t}$ is the real GDP; the interest rate growth, $\Delta I R_{i, t}=i r s_{i, t}-i r s_{i, t-1}$, where $i r s_{i, t}$ is the short term (3 months) interest rate; and the growth rate of government expenditures, $\Delta G_{i, t}=\Delta \ln \left(g c_{i, t}\right)$, where $g c_{i, t}$ is the general 
government final consumption expenditure for each country. ${ }^{6}$ Following Caporale et al. (1996) and Bakas et al. (2016), we proxy the monetary policy variability using the conditional variance $\left(H_{i, t}\right)$ derived from a GARCH $(1,1)$ model for the interest rate. Given the literature reviewed in Baker et al. (2015), we consider augmenting the specification with several measures of volatility (expected volatility and stock market volatility) for the EU (and the US). 7,8 Table 2 presents the corresponding summary statistics for all variables used in our analysis. Figure 1 shows the sectoral reallocation index for the $15 \mathrm{EU}$ countries against the EU average. Figure 2 presents the country-by-country graphs of the unemployment rate and the dispersion index for the EU panel. The heterogeneity of the EU labor markets (both in terms of the unemployment rate as well the dispersion index) is evident from both Figures. It is crucial to account for this heterogeneity (alongside with the inherent interdependence across the EU countries) in our panel data analysis.

\section{EMPIRICAL RESULTS}

We present a (preliminary) graphical investigation of the relationship between the sectoral reallocation index $\left(\sigma^{p}\right)$ and the unemployment rate for the $15 \mathrm{EU}$ countries in Figure 3. The graph reveals the positive relationship between the Lilien's proxy and unemployment rate for the $15 \mathrm{EU}$ countries over the period 1995Q1-2015Q1 with a statistically significant correlation coefficient of 0.278 . This positive correlation is further confirmed by the Pooled OLS and the CCEMG regression lines between the Lilien's proxy and the unemployment rate. It also highlights the differences in the Lilien's sigma slope coefficient between the homogeneous (POLS) and the heterogeneous (CCEMG) models.

Our analysis continues with the estimation of Equation (1) using an extended dataset of 15 EU countries over the period 1995Q1-2015Q1 (a total of 1165 observations after

\footnotetext{
${ }^{6}$ We use the short term interest rates obtained by the national Central Banks, while after the introduction of the euro we use the 3-month "European Interbank Offered Rate" from the ECB for the period after each country joined the single currency.

${ }^{7}$ We use the VSTOXX volatility index $\left(V O L^{e u}\right)$, obtained from STOXX database, for the EU stock market variability (which is the European equivalent to the VIX index for the US), and the EPU index of Baker et al. (2015) for EU and US (EPU eu and EPU ${ }^{u s}$ ) respectively (source: http://www.policyuncertainty.com/). Finally, we use a stock market index (STOCK ${ }^{e u}$ ) for each country (collected from the OECD database).

8 Bloom (2013) defines "uncertainty" as forward looking and volatility as realised. Uncertainty can be viewed as 'expected volatility'.
} 
adjustments). ${ }^{9}$ Table 3 presents the estimated coefficients of Equation (1) using alternative homogeneous estimation techniques: Pooled OLS, (one way and two way) Fixed Effects, system GMM, the Driscoll and Kraay's (1998) Pooled OLS and Fixed Effects estimators which produces robust standard errors to cross-sectional dependence and the Pesaran's (2006) Pooled Common Correlated Effects estimator (without and with state-specific linear trend) that accounts for cross sectional dependence. ${ }^{10}$ The coefficient of lagged unemployment is significant and less than unity (greater than 0.9 but lower than 1) capturing the high persistent nature of unemployment. The coefficient of labor reallocation as measured by Lilien's proxy $\left(\sigma^{p}\right)$ is positive and statistically significant across all alternative estimation methods (including the Driscoll and Kraay's (1998) and the Pesaran's (2006) estimators that are robust to cross-sectional dependence and the system GMM approach which is robust to endogeneity issues of the regressors). The values of the $\sigma^{p}$ coefficients range from 0.82 (CCEP) to $1.291\left(\mathrm{FE}_{\mathrm{T}}\right)$ and are statistically significant in all cases highlighting the importance of labor reallocation for unemployment. ${ }^{11}$ These findings reinforce the existing evidence of a significant effect of sectoral shocks (e.g. De Serres et al. (2002) for the EU and Bakas et al. (2016) for the US). The coefficient of the growth rate of GDP is negative and significant and, in a sense, reflects Okun's law. The coefficient of $\Delta I R$ is also negative and significant in most of the cases, but with relatively lower significance for unemployment, while $H$ (the monetary policy GARCH variability) has a small positive and significant coefficient. Finally, the impact of the fiscal policy $(\Delta G)$ is found to be negative and significant.

Table 4 presents the heterogeneous slopes estimates that account for cross-sectional dependence (AMG, CCEMG and the dynCCEMG which allows for lagged values of the dependent variable and weakly exogenous regressors in the specification). The coefficient of $\sigma^{p}$ remains positive and significant in all cases with values just below unity (ranging from $0.748(\mathrm{CCEMGT})$ to 0.880 (CCEMG)). The results based on the heterogeneous estimators (Table 4) highlight the significant effect of the dispersion index on

\footnotetext{
${ }^{9}$ We estimate Equation (1) using the 'purged' dispersion index $\sigma^{p}$ to isolate the impact of the idiosyncratic component of the dispersion index. Substituting the purged proxy with the unpurged measure would not alter the outcomes qualitatively. These results are available upon request.

10 Since our focus is on addressing the existing heterogeneity (and cross sectional dependence) in the EU data, we start by implementing several pooled estimators as benchmark cases before moving to heterogeneous approaches for comparison purposes. We would like to thank an anonymous referee for drawing our attention to this point.

${ }^{11}$ Bakas et al. (2016) provide lower estimates of labor reallocation for the US.
} 
unemployment when both heterogeneity and interdependence among EU states are taken into account (albeit lower to the homogenous case). Furthermore, we observe that these heterogeneous estimates (Table 4) are of similar magnitude with the estimates of the pooled CCE estimator (columns 7 and 8 of Table 3) where cross country dependence is taken into account. ${ }^{12}$ This outcome stresses the importance of controlling for the presence of cross sectional dependence in the European panel context. The estimated value of 1.277 based on the FE estimator declines to 0.82 and 0.88 under the homogeneous CCEP and the heterogeneous CCEMG estimators respectively. The results for lagged unemployment confirm the high persistence of unemployment. The rest of the coefficients are producing results similar to the pooled estimates both in significance and sign.

Having established a significantly positive unemployment effect of labor reallocation, we focus on the magnitude of the impact of labor reallocation on unemployment for the EU states. The $\sigma^{p}$ coefficient measures the semi-elasticity of unemployment with respect to the labor reallocation index. We use the estimates generated by the homogeneous DK-FE (column 6 of Table 3) and the heterogeneous CCEMG (column 2 of Table 4) estimators to measure the unemployment response to labor reallocation changes. The coefficient of the DK-FE model suggests an estimated elasticity (the percentage change in unemployment rate in response to a percentage change in the dispersion index) of $1.28 \%$ at the sample mean of sigma $(\bar{\sigma}=0.01)$. The impact decreases slightly when we use the CCEMG estimate (a $1 \%$ increase in the reallocation index will lead to a $0.88 \%$ increase of the unemployment rate for the EU states). ${ }^{13}$

In addition, a one sample standard deviation increase in the labor reallocation index results in an increase from 1.015 (CCEMG) to 1.021 (DK-FE) standard deviations in the rate of unemployment. ${ }^{14}$ Using the standardized coefficients based on the CCEMG and the DK-FE estimators, we can compare the magnitude of the effect of the reallocation index with that of the GDP growth as well as with the impact of the monetary and fiscal policy change. A one standard deviation increase in the measure of labor reallocation leads to an

\footnotetext{
${ }^{12}$ Following the theoretical argument of Sarafidis and Wansbeek (2012) and analogously to the findings in Bakas et al. (2016), we observe that neglecting to account for cross sectional dependence in the estimation will lead to an upward bias in the estimates.

${ }^{13}$ Similarly, the elasticity of unemployment with respect to sigma (based on the CCEMG estimator) will be equal to $6.16 \%$ at the sample maximum value of the reallocation index $\left(\sigma_{\max }=0.07\right)$ (see Table 2$)$.

${ }^{14}$ The estimated standardized coefficient for the reallocation index is 0.021 (DK-FE) and 0.015 (CCEMG) respectively. The reallocation index has a sample standard deviation of about 0.007 (see Table 2).
} 
increase of about 0.015 standard deviations ( 0.021 based on the DK-FE) in the logarithm of the unemployment rate while a one standard deviation increase in the growth of GDP is associated with a decrease of 0.018 standard deviations (0.031 on the DK-FE) in the logarithm of unemployment rate. Similarly, a one standard deviation increase in the $\Delta I R$ is associated with a decrease of 0.02 standard deviations (statistically significant with the DK-FE) in the logarithm of unemployment rate and, finally, a one standard deviation increase in the $\Delta G$ is associated with a decrease of 0.008 standard deviations $(0.011$ with the DK-FE) in the logarithm of unemployment rate. Thus, the impact of reallocation index on unemployment rate is of similar magnitude with the impact of the GDP growth and that of the change of the monetary policy instrument and roughly double the impact of the fiscal policy growth (in absolute value).

\section{A. ROBUSTNESS}

Our robustness analysis is twofold. First, alternative $\sigma^{p}$ indexes are constructed to investigate whether the degree of sectoral disaggregation can affect the results (i.e. we vary the number of sectors entering the computation of Equation (2)). Table 5 presents the results for labor reallocation that stems from several dispersion proxies measured using alternative sectoral decompositions $\left(4,5,8,9\right.$ and 10 sectors). The 10 sector $\sigma^{p}$ index is also employed by repeating the results presented in column 6 of Table 3 and column 2 of Table 4. These outcomes were computed using the homogeneous DK-FE and the heterogeneous CCEMG estimators. ${ }^{15}$ Two issues emerge from the results. First and foremost, we observe that the coefficient of labor reallocation remains positive and significant under all alternative measures of sectoral disaggregation. Second, the magnitude of the $\sigma^{p}$ coefficient decreases as the sectoral disaggregation increases, a result that corroborates Parker's (1992) support for the importance of mobility across the 4 major sectors of the economy. ${ }^{16}$ The coefficient of $\Delta I R$ seems to be more fragile to the alternative measures of reallocation index in the specification as it loses its significance in some cases when employing the CCEMG estimator.

\footnotetext{
${ }^{15}$ We explore the robustness of our results by implementing the heterogeneous CCEMG (that accounts also for cross sectional dependence) and a homogeneous counterpart estimator, the DK-FE, to facilitate comparisons.

${ }^{16}$ As in Bakas et al. (2016), the impact of the dispersion index depends on the level of its disaggregation. The extent of sectoral decomposition determines the magnitude of labor restructuring that is captured. One limitation is that it cannot capture intrasectoral and intrafirm reallocation.
} 
The second route is to consider measures of (expected) volatility and stock market volatility in the empirical specification. Following the contributions of Bloom $(2009,2013)$ and Baker et al. (2015) we augment the model by considering the effects of volatility. Expected volatility is proxied by the Economic Policy Uncertainty Index (EPU ${ }^{e u}$ and EPU us) for Europe and the US (see Baker et al. (2015) for an extensive discussion). Alternative measures of volatility include the EU stock market variability index $\left(V O L^{e u}\right)$ that is measured by the VSTOXX volatility index. Finally, we use the stock market index for each country $\left(S T O C K^{e u}\right)$ as a proxy for the stock market activity. The results are presented in Table 6 and Table 7 using the homogeneous DK-FE and the heterogeneous CCEMG estimators respectively. Two points emerge from these results. First, looking at Table 6, the measures of expected volatility (EPU for Europe and the US) and stock market volatility $\left(V O L^{e u}\right)$ are affecting in a positive and significant way unemployment (stock market index (STOCKeu ) has a significant negative sign instead). ${ }^{17}$ This finding corroborates Caggiano et al. (2014) and Baker at al. (2015) who provide evidence of a significant positive effect of unemployment to volatility and uncertainty shocks. Second, $\sigma^{p}$ remains positive and significant under all different scenarios (with a magnitude comparable to those produced from the specification without the volatility proxies). Choi and Loungani (2015) document the higher importance of sectoral (uncertainty) shocks on unemployment compared to aggregate (uncertainty) shocks for the US. The relative lower estimated coefficients of EPU on Table 6 seem to point to the same direction for the EU. Overall the purged dispersion measure remains significant under alternative levels of sectoral disaggregation and when expected volatility and stock market volatility are taken into account.

\section{CONCLUSIONS}

The notion of labor reallocation and its effect on unemployment has generated a strand of literature that focused on the US economy. We revisit the hypothesis by looking at an extensive panel of 15 European countries. The adopted econometric methodology takes into account important characteristics of the hypothesis: dynamics, heterogeneity and cross section dependence. We construct an extensive quarterly panel dataset of 1165

\footnotetext{
${ }^{17}$ The variables EPU ${ }^{e u}, E P U^{u s}$ and $V O L^{e u}$ are common for all EU countries and can be seen as 'observed common factors' in the heterogeneous version of Equation (1) and therefore their coefficients and its significance based on the CCEMG estimator (in Table 7) have to interpreted with caution.
} 
observations. The increased degrees of freedom of the panel framework allow the assessment of the effect of labor reallocation on European unemployment. We employ a battery of alternative pooled and heterogeneous panel estimates. All estimations bear out the positive and statistically significant effect of labor reallocation on unemployment. Robustness includes different labor sectoral disaggregation and the inclusion of alternative volatility measures. These results confirm the economic importance of labor reallocation for the European unemployment. 


\section{REFERENCES}

Abraham, K. G. and L. F. Katz (1988), Cyclical Unemployment: Sectoral Shifts or Aggregate Disturbances? Journal of Political Economy, 94, 507-522.

Aghion, P. and P. Howitt (1992), A Model of Growth through Creative Destruction. Econometrica, 60, 323-351.

Bakas, D., Panagiotidis, T. and G. Pelloni (2016), Regional and Sectoral Evidence of the Macroeconomic Effects of Labor Reallocation: A Panel Data Analysis. Economic Inquiry, forthcoming.

Baker, S., Bloom, N. and S. J. Davis (2015), Measuring Economic Policy Uncertainty. Working Paper Series, Working Paper 21633, National Bureau of Economic Research.

Beyer, R. C.M. and F. Smets (2015), Labour Market Adjustments in Europe and the US. How Different? Economic Policy, 30, 643-682.

Blanchard, O. J. and L. F. Katz (1992), Regional Evolutions. Brookings Papers on Economic Activity, 23, 1-76.

Bloom, N. (2009), The Impact of Uncertainty Shocks. Econometrica, 77, 623-685.

Bloom, N. (2013), The Macroeconomics of Time Varying Uncertainty. Mimeo.

Blundell, R. and S. Bond (1998), Initial Conditions and Moment Restrictions in Dynamic Panel Data Models. Journal of Econometrics, 87, 115-143.

Bond, S. and M. Eberhardt (2009), Cross-Section Dependence in Nonstationary Panel Models: a Novel Estimator. MPRA Paper 17692, University Library of Munich.

Caporale, T., K. Doroodian and M. R. M. Abeyratne (1996), Cyclical Unemployment: Sectoral Shifts or Aggregate Disturbances? A Vector Autoregression Approach. Applied Economics Letters, 3, 127-130.

Caggiano, G., E. Castelnuovo and N. Groshenny (2014), Uncertainty Shocks and Unemployment Dynamics in US Recessions. Journal of Monetary Economics, 67, 78-92.

Choi S. and P. Loungani (2015), Uncertainty and Unemployment: The Effects of Aggregate and Sectoral Channels. Journal of Macroeconomics, 46, 344-358.

Chudik, A. and M. H. Pesaran (2015a), Common Correlated Effects Estimation of Heterogenous Dynamic Panel Data Models with Weakly Exogenous Regressors. Journal of Econometrics, 188, 393-420. 
Chudik, A. and M. H. Pesaran (2015b), Large Panel Data Models with Cross-Sectional Dependence: A Survey. In The Oxford Handbook on Panel Data, edited by B. H. Baltagi. Oxford: Oxford University Press.

Chudik, A., M. H. Pesaran and E. Tosetti (2011), Weak and Strong Cross-Section Dependence and Estimation of Large Panels. Econometrics Journal, 14, C45-C90.

Dao, M., D. Furceri and P. Loungani (2014), Regional Labor Market Adjustments in the United States. IMF Working Papers 14/211, International Monetary Fund.

De Grauwe, P. (2016), The Legacy of the Eurozone Crisis and how to Overcome it. Journal of Empirical Finance, forthcoming.

De Serres, A., S. Scarpetta and C. De La Maisonneuve (2002), Sectoral Shifts in Europe and the United States: How They Affect Aggregate Labour Shares and the Properties of Wage Equations. OECD Economics Department Working Papers 326, OECD Publishing.

Draghi, M. (2014), Unemployment in the Euro Area. Speech by Mario Draghi, President of the ECB, Annual central bank symposium in Jackson Hole, 22 August, European Central Bank, https:// www.ecb.europa.eu/press/key/date/2014/html/sp140822.en.html.

Driscoll, J. C. and A. C. Kraay (1998), Consistent Covariance Matrix Estimation with Spatially Dependent Panel Data. The Review of Economics and Statistics, 80, 549-560.

European Central Bank (2012), Euro Area Labour Markets and the Crisis, Structural Issues Report. October, European Central Bank,

https://www.ecb.europa.eu/pub/pdf/other/euroarealabourmarketsandthecrisis201210en.pdf.

Gallipoli G. and Pelloni G. (2013), Aggregate Shocks vs Reallocation Shocks: An Appraisal of the Applied Literature. Review of Economic Analysis, 5, 127-176.

Hogrefe J. and A. Sachs (2014), Unemployment and Labor Reallocation in Europe. ZEW Discussion Papers, No. 14-083, Zentrum für Europäische Wirtschaftsforschung.

Lilien D. M. (1982), Sectoral Shifts and Cyclical Unemployment. Journal of Political Economy, 90, 777-793.

Mills, T. C., G. Pelloni and A. Zervoyianni (1995), Unemployment Fluctuations in the United States: Further Tests of the Sectoral-Shifts Hypothesis. The Review of Economics and Statistics, 77, 294-304.

Okun, A. M. (1962), Potential GNP, its Measurement and Significance. Cowles Foundation, Yale University.

Parker, J. (1992), Structural Unemployment in the United States: The Effects of Interindustry and Interregional Dispersion. Economic Inquiry, 30, 101-16. 
Pesaran, M. H. (2006), Estimation and Inference in Large Heterogeneous Panels with a Multifactor Error Structure. Econometrica, 74, 967-1012.

Sarafidis, V. and T. Wansbeek (2012), Cross-Sectional Dependence in Panel Data Analysis. Econometric Reviews, 31, 483-531.

Schumpeter, J. A. (1976), Capitalism, Socialism and Democracy. Routledge, 5th Edition. 


\section{PART A: DESCRIPTIVE STATISTICS}

Table 1: List of EU Countries and Abbreviations

\begin{tabular}{lclc}
\hline Country & Abbrev. & \multicolumn{1}{c}{ Country } & Abbrev. \\
\hline Austria & AT & Italy & IT \\
Belgium & BE & Luxembourg & LU \\
Denmark & DK & Netherlands & NL \\
Finland & FI & Portugal & PT \\
France & FR & Spain & ES \\
Germany & DE & Sweden & SE \\
Greece & GR & United Kingdom & GB \\
Ireland & IE & \multicolumn{2}{c}{$N=15, T=81, O b s=1165$} \\
& & \multicolumn{2}{c}{} \\
\hline
\end{tabular}

Table 2: Summary Statistics

\begin{tabular}{|c|c|c|c|c|}
\hline & Mean & SD & Min & $\operatorname{Max}$ \\
\hline & \multicolumn{4}{|c|}{ Sectoral Variables } \\
\hline Total & 11897.88 & 12040.59 & 257.45 & 42774.00 \\
\hline Agriculture & 412.58 & 341.60 & 4.04 & 1280.50 \\
\hline Industry & 1933.55 & 2205.59 & 36.31 & 8880.00 \\
\hline Construction & 841.82 & 845.01 & 27.78 & 3332.00 \\
\hline Trade & 2941.81 & 2938.34 & 65.97 & 9884.00 \\
\hline Information & 336.32 & 373.98 & 8.33 & 1382.02 \\
\hline Financial & 354.35 & 390.07 & 29.06 & 1298.00 \\
\hline Real Estate & 120.64 & 144.11 & 1.39 & 503.13 \\
\hline Professional & 1359.43 & 1476.80 & 28.14 & 5667.00 \\
\hline Public Sector & 2836.50 & 2908.46 & 43.82 & 10278.00 \\
\hline \multirow[t]{2}{*}{ Other Sectors } & 760.87 & 873.61 & 11.07 & 2992.00 \\
\hline & \multicolumn{4}{|c|}{ Macro Variables } \\
\hline Un. Rate (\%) & 8.337 & 4.172 & 1.867 & 27.833 \\
\hline$U(\log )$ & -2.588 & 0.449 & -3.981 & -1.279 \\
\hline$\sigma$ & 0.010 & 0.007 & 0.001 & 0.069 \\
\hline$\sigma^{p}$ & 0.000 & 0.007 & -0.012 & 0.060 \\
\hline Real GDP (log) & 11.753 & 1.242 & 8.648 & 13.827 \\
\hline Int. Rate (\%) & 3.091 & 2.415 & -0.113 & 18.117 \\
\hline$H^{G A R C H}$ & 0.462 & 0.513 & 0.000 & 8.797 \\
\hline Gov. Exp. (log) & 10.160 & 1.323 & 6.682 & 12.488 \\
\hline$E P U^{e u}$ & 4.751 & 0.347 & 4.100 & 5.555 \\
\hline EPU us & 4.613 & 0.303 & 4.145 & 5.375 \\
\hline$V O L^{e u}$ & 3.174 & 0.325 & 2.569 & 4.066 \\
\hline STOCK eu & 4.541 & 0.429 & 3.247 & 5.817 \\
\hline
\end{tabular}




\section{PART B: FIGURES}

Figure 1: Lilien's "Purged" Index for the 15 EU Countries against the EU average
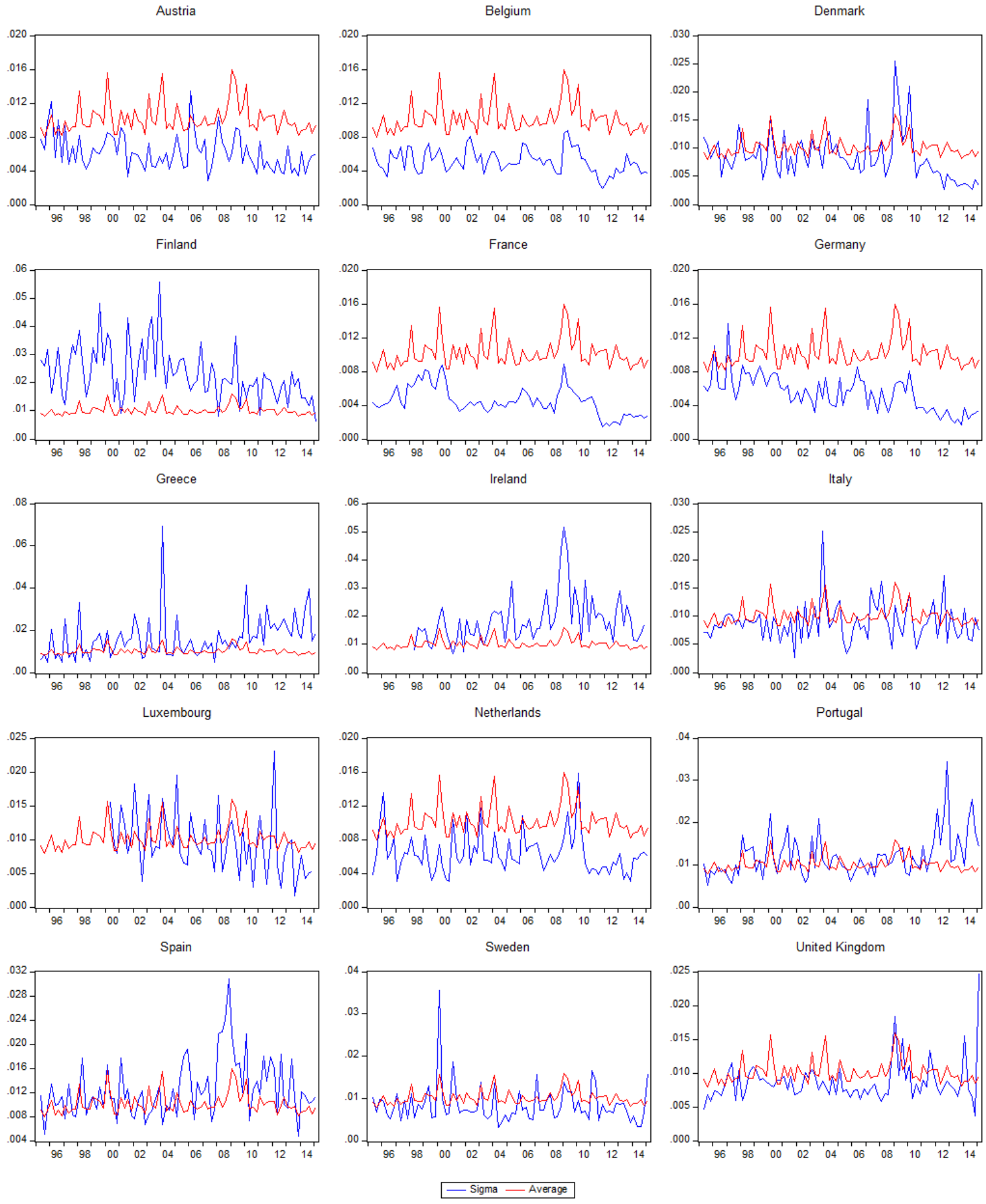
Figure 2: Unemployment Rate and Lilien's "Purged" Index for the 15 EU Countries
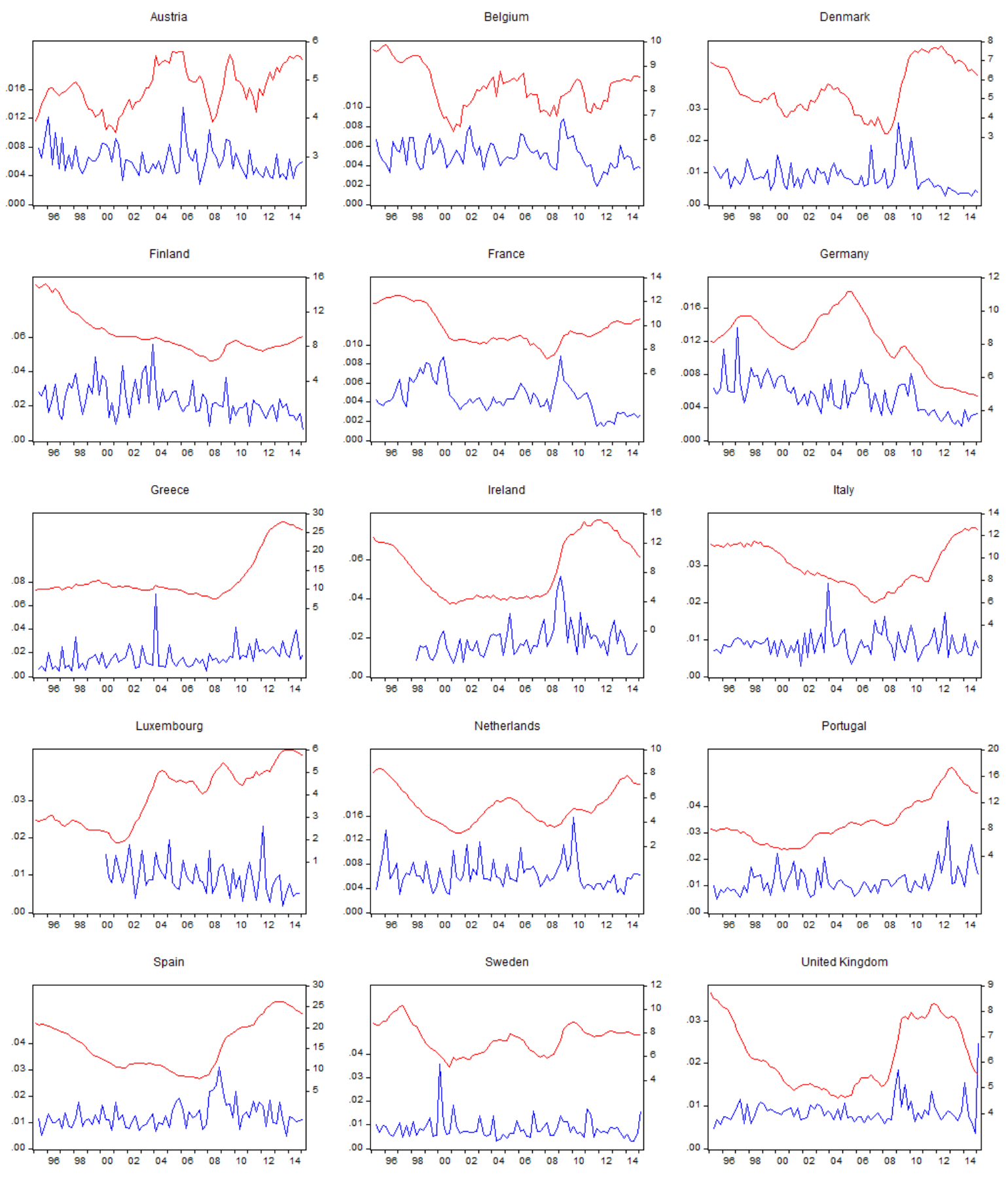
Figure 3: Cross Country Correlation between Unemployment Rate and Lilien's "Purged" Index for the 15 EU Countries

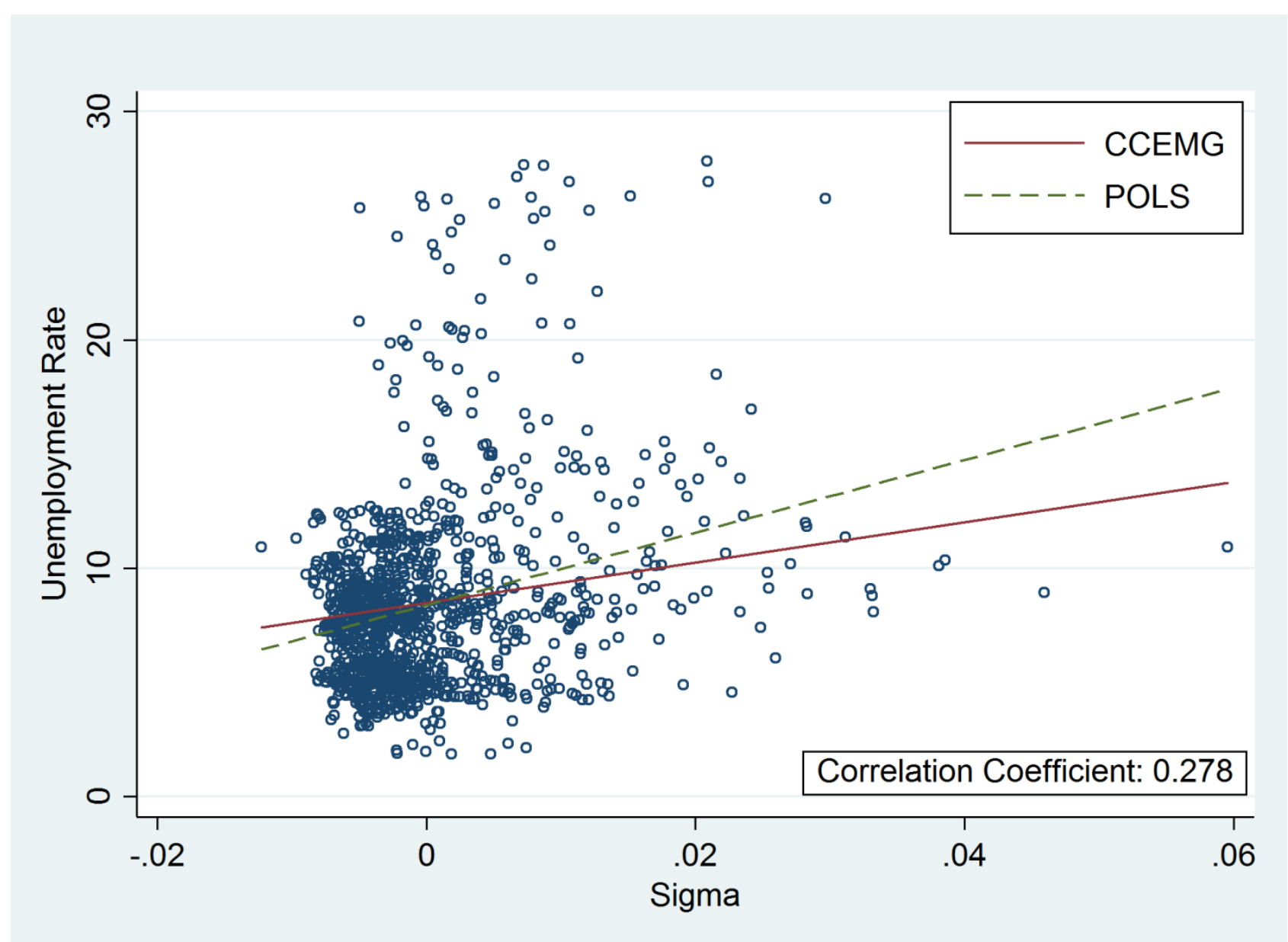


PART C: ESTIMATION TABLES

Table 3: Lilien's Index and Sectoral Shifts - Pooled Estimates

\begin{tabular}{|c|c|c|c|c|c|c|c|c|}
\hline & POLS & FE & $\mathrm{FE}_{\mathrm{T}}$ & GMM & DK-POLS & DK-FE & CCEP & $\mathrm{CCEP}_{\mathrm{T}}$ \\
\hline$U_{\text {Lagged }}$ & $\begin{array}{c}0.984^{* *} \\
(292.51)\end{array}$ & $\begin{array}{c}0.973^{* *} \\
(161.34)\end{array}$ & $\begin{array}{c}0.975^{* *} \\
(136.64)\end{array}$ & $\begin{array}{l}0.978^{* *} \\
(88.81)\end{array}$ & $\begin{array}{c}0.984^{* *} \\
(181.71)\end{array}$ & $\begin{array}{c}0.973^{* *} \\
(105.34)\end{array}$ & $\begin{array}{c}0.966^{* *} \\
(135.35)\end{array}$ & $\begin{array}{c}0.965^{* *} \\
(129.57)\end{array}$ \\
\hline$\sigma^{p}$ & $\begin{array}{c}0.905^{* *} \\
(4.32)\end{array}$ & $\begin{array}{l}1.277^{* *} \\
(2.65)\end{array}$ & $\begin{array}{l}1.291^{* *} \\
(2.71)\end{array}$ & $\begin{array}{c}0.976^{* *} \\
(2.23)\end{array}$ & $\begin{array}{c}0.905^{* *} \\
(2.59)\end{array}$ & $\begin{array}{l}1.277^{* *} \\
(2.61)\end{array}$ & $\begin{array}{c}0.820^{* *} \\
(3.44)\end{array}$ & $\begin{array}{c}0.827^{* *} \\
(3.33)\end{array}$ \\
\hline$\triangle G D P$ & $\begin{array}{l}-1.020^{* *} \\
(-7.64)\end{array}$ & $\begin{array}{c}-1.027^{* *} \\
(-4.18)\end{array}$ & $\begin{array}{c}-0.599^{* *} \\
(-3.57)\end{array}$ & $\begin{array}{c}-1.090^{* *} \\
(-4.47)\end{array}$ & $\begin{array}{c}-1.020^{* *} \\
(-5.58)\end{array}$ & $\begin{array}{c}-1.027^{* *} \\
(-6.01)\end{array}$ & $\begin{array}{c}-0.345^{* *} \\
(-2.37)\end{array}$ & $\begin{array}{l}-0.337^{* *} \\
(-2.23)\end{array}$ \\
\hline$\Delta I R$ & $\begin{array}{c}-0.018^{* *} \\
(-4.04)\end{array}$ & $\begin{array}{c}-0.018^{* *} \\
(-2.54)\end{array}$ & $\begin{array}{l}-0.003 \\
(-0.54)\end{array}$ & $\begin{array}{c}-0.021^{* *} \\
(-3.22)\end{array}$ & $\begin{array}{c}-0.018^{* *} \\
(-2.79)\end{array}$ & $\begin{array}{c}-0.018^{* *} \\
(-2.90)\end{array}$ & $\begin{array}{l}-0.004 \\
(-1.24)\end{array}$ & $\begin{array}{l}-0.004 \\
(-1.20)\end{array}$ \\
\hline$H$ & $\begin{array}{c}0.011^{* *} \\
(4.35)\end{array}$ & $\begin{array}{c}0.010^{* *} \\
(4.58)\end{array}$ & $\begin{array}{c}0.012^{* *} \\
(5.76)\end{array}$ & $\begin{array}{c}0.011^{* *} \\
(3.40)\end{array}$ & $\begin{array}{c}0.011^{* *} \\
(2.89)\end{array}$ & $\begin{array}{l}0.010^{* *} \\
(2.46)\end{array}$ & $\begin{array}{c}0.012^{* *} \\
(4.73)\end{array}$ & $\begin{array}{c}0.012^{* *} \\
(4.51)\end{array}$ \\
\hline$\Delta G$ & $\begin{array}{c}-0.230^{* *} \\
(-2.90)\end{array}$ & $\begin{array}{l}-0.287^{*} \\
(-1.98)\end{array}$ & $\begin{array}{l}-0.269^{*} \\
(-2.13)\end{array}$ & $\begin{array}{l}-0.299^{*} \\
(-1.70)\end{array}$ & $\begin{array}{l}-0.230^{* *} \\
(-3.14)\end{array}$ & $\begin{array}{c}-0.287^{* *} \\
(-4.40)\end{array}$ & $\begin{array}{l}-0.220^{* *} \\
(-2.76)\end{array}$ & $\begin{array}{l}-0.217^{* *} \\
(-2.62)\end{array}$ \\
\hline Obs & 1165 & 1165 & 1165 & 1165 & 1165 & 1165 & 1165 & 1165 \\
\hline$N$ & 15 & 15 & 15 & 15 & 15 & 15 & 15 & 15 \\
\hline$T$ & 78 & 78 & 78 & 78 & 78 & 78 & 78 & 78 \\
\hline $\begin{array}{l}\text { RMSE } \\
\text { Hansen-J } \\
A R(1) \\
A R(2)\end{array}$ & 0.0396 & 0.0389 & 0.0359 & $\begin{array}{c}0.0397 \\
1.00 \\
0.00 \\
0.40\end{array}$ & 0.0396 & 0.0399 & 0.0324 & 0.0335 \\
\hline
\end{tabular}

Notes: FE and $F E_{T}$ - one way and two way Fixed Effects estimator respectively. DK POLS and DK FE -Driscoll and Kraay's (1998) Pooled OLS and Fixed Effects estimators. GMM - Blundell and Bond (1998) System GMM estimator. CCE and $C C E_{T}$ - the Pesaran (2006) pooled common correlated effects estimator (without and with state-specific linear trend). $t$-statistics in parentheses. All estimations were carried out using robust standard errors. RMSE refers to the root mean squared error. Hansen J refers to the p-value of the Hansen test for the validity of over-identifying restrictions. AR (1) and AR (2) refer to the p-value of the test for first-order and second-order residual serial correlation. ${ }^{*}$ and ${ }^{*}$ denotes significance at the $10 \%$ and $5 \%$ significance levels, respectively. 
Table 4: Lilien's Index and Sectoral Shifts - Heterogeneous Estimates

\begin{tabular}{|c|c|c|c|c|c|}
\hline & AMG & CCEMG & $\mathrm{CCEMGT}_{\mathrm{T}}$ & dynCCEMG $_{1}$ & $\mathrm{dynCCEMG}_{4}$ \\
\hline \multirow[t]{2}{*}{$U_{\text {Lagged }}$} & $0.939^{* *}$ & $0.942^{* *}$ & $0.944^{* *}$ & $0.944^{* *}$ & $0.917^{* *}$ \\
\hline & $(62.78)$ & (53.43) & (52.98) & (56.28) & $(42.12)$ \\
\hline \multirow[t]{2}{*}{$\sigma^{p}$} & $0.831^{* *}$ & $0.880^{* *}$ & $0.748^{* *}$ & $0.856^{* *}$ & $0.828^{*}$ \\
\hline & $(2.27)$ & $(3.08)$ & $(2.61)$ & $(2.61)$ & $(1.72)$ \\
\hline \multirow[t]{2}{*}{$\triangle G D P$} & $-0.986^{* *}$ & $-0.585^{* *}$ & $-0.601^{* *}$ & $-0.461^{* *}$ & $-0.506^{*}$ \\
\hline & $(-3.22)$ & $(-3.08)$ & $(-2.51)$ & $(-2.27)$ & $(-1.81)$ \\
\hline \multirow[t]{2}{*}{$\Delta I R$} & $-0.022^{* *}$ & -0.043 & -0.045 & -0.002 & -0.008 \\
\hline & $(-5.32)$ & $(-1.52)$ & $(-1.56)$ & $(-0.28)$ & $(-1.32)$ \\
\hline \multirow[t]{2}{*}{$H$} & $0.010^{* *}$ & $0.046^{*}$ & $0.052^{*}$ & 0.004 & 0.005 \\
\hline & $(2.17)$ & (1.75) & (1.93) & $(0.71)$ & (1.05) \\
\hline \multirow[t]{2}{*}{$\Delta G$} & -0.089 & $-0.218^{* *}$ & $-0.184^{*}$ & $-0.179^{*}$ & $-0.278^{* *}$ \\
\hline & $(-0.68)$ & $(-2.37)$ & $(-1.89)$ & $(-1.80)$ & $(-2.04)$ \\
\hline Obs & 1165 & 1165 & 1165 & 1152 & 1113 \\
\hline$N$ & 15 & 15 & 15 & 15 & 15 \\
\hline$T$ & 78 & 78 & 78 & 77 & 74 \\
\hline RMSE & 0.0342 & 0.0285 & 0.0282 & 0.0279 & 0.0229 \\
\hline
\end{tabular}

Notes: AMG - Bond and Eberhardt's (2009) Augmented Mean Group estimator. CCEMG and CCEMG - Pesaran's $^{\text {' }}$ (2006) Common Correlated Effects Mean Group estimator (without and with state-specific linear trend). dynCCEMG 1 and dynCCEMG 4 - Chudik and Pesaran's (2015a) Dynamic Common Correlated Effects Mean Group estimator (augmented with one and four additional lags of the cross-section averages). $t$-statistics in parentheses. RMSE refers to the root mean squared error. ${ }^{*}$ and ${ }^{* *}$ denotes significance at the $10 \%$ and $5 \%$ significance levels, respectively. 
Table 5: Lilien's Index and Sectoral Shifts - Alternative Sectoral Decomposition

\begin{tabular}{|c|c|c|c|c|c|c|c|c|c|c|}
\hline & DK-FE & CCEMG & DK-FE & CCEMG & DK-FE & CCEMG & DK-FE & CCEMG & DK-FE & CCEMG \\
\hline$U_{\text {Lagged }}$ & $\begin{array}{c}0.973^{\text {** }} \\
(105.76)\end{array}$ & $\begin{array}{l}0.943^{\text {t* }} \\
(56.26)\end{array}$ & $\begin{array}{c}0.974^{* *} \\
(108.87)\end{array}$ & $\begin{array}{l}0.943^{* *} \\
(57.34)\end{array}$ & $\begin{array}{c}0.973^{* *} \\
(105.03)\end{array}$ & $\begin{array}{l}0.941^{* *} \\
(51.96)\end{array}$ & $\begin{array}{c}0.973^{\text {t* }} \\
(106.33)\end{array}$ & $\begin{array}{l}0.941^{\text {*t }} \\
(53.33)\end{array}$ & $\begin{array}{c}0.973^{\text {** }} \\
(105.34)\end{array}$ & $\begin{array}{l}0.942^{* *} \\
(53.43)\end{array}$ \\
\hline$\sigma_{4}^{p}$ & $\begin{array}{l}2.097^{\text {** }} \\
(3.29)\end{array}$ & $\begin{array}{l}1.207^{\text {** }} \\
(3.62)\end{array}$ & & & & & & & & \\
\hline$\sigma_{5}^{p}$ & & & $\begin{array}{l}2.243^{* *} \\
(3.88)\end{array}$ & $\begin{array}{l}1.158^{* *} \\
(3.32)\end{array}$ & & & & & & \\
\hline$\sigma_{8}^{p}$ & & & & & $\begin{array}{l}1.199^{* *} \\
(2.29)\end{array}$ & $\begin{array}{l}0.981^{* *} \\
(2.67)\end{array}$ & & & & \\
\hline$\sigma_{9}^{p}$ & & & & & & & $\begin{array}{l}1.394^{* *} \\
(2.74)\end{array}$ & $\begin{array}{l}1.030^{* *} \\
(3.24)\end{array}$ & & \\
\hline$\sigma_{10}^{p}$ & & & & & & & & & $\begin{array}{l}1.277^{\text {*t }} \\
(2.61)\end{array}$ & $\begin{array}{l}0.880^{* *} \\
(3.08)\end{array}$ \\
\hline$\triangle G D P$ & $\begin{array}{c}-1.070^{* *} \\
(-6.24)\end{array}$ & $\begin{array}{c}-0.647^{* *} \\
(-3.32)\end{array}$ & $\begin{array}{l}-1.060^{\text {** }} \\
(-6.49)\end{array}$ & $\begin{array}{c}-0.629^{* *} \\
(-3.27)\end{array}$ & $\begin{array}{c}-1.073^{\star *} \\
(-5.92)\end{array}$ & $\begin{array}{c}-0.656^{* *} \\
(-3.50)\end{array}$ & $\begin{array}{c}-1.067^{* *} \\
(-6.07)\end{array}$ & $\begin{array}{c}-0.650^{* *} \\
(-3.45)\end{array}$ & $\begin{array}{c}-1.027^{\text {** }} \\
(-6.01)\end{array}$ & $\begin{array}{c}-0.585^{* *} \\
(-3.08)\end{array}$ \\
\hline$\Delta I R$ & $\begin{array}{c}-0.018^{* *} \\
(-2.87)\end{array}$ & $\begin{array}{l}-0.039^{*} \\
(-1.72)\end{array}$ & $\begin{array}{l}-0.018^{* *} \\
(-2.95)\end{array}$ & $\begin{array}{l}-0.039^{*} \\
(-1.71)\end{array}$ & $\begin{array}{c}-0.018^{* *} \\
(-2.83)\end{array}$ & $\begin{array}{l}-0.042 \\
(-1.54)\end{array}$ & $\begin{array}{c}-0.018^{\star *} \\
(-2.87)\end{array}$ & $\begin{array}{l}-0.041 \\
(-1.56)\end{array}$ & $\begin{array}{c}-0.018^{* *} \\
(-2.90)\end{array}$ & $\begin{array}{l}-0.043 \\
(-1.52)\end{array}$ \\
\hline$H$ & $\begin{array}{c}0.010^{* *} \\
(2.57)\end{array}$ & $\begin{array}{l}0.045^{*} \\
(1.73)\end{array}$ & $\begin{array}{l}0.010^{* *} \\
(2.85)\end{array}$ & $\begin{array}{l}0.045^{*} \\
(1.76)\end{array}$ & $\begin{array}{l}0.010^{* *} \\
(2.34)\end{array}$ & $\begin{array}{l}0.047^{\star} \\
(1.71)\end{array}$ & $\begin{array}{c}0.010^{\text {** }} \\
(2.52)\end{array}$ & $\begin{array}{l}0.047^{\star} \\
(1.71)\end{array}$ & $\begin{array}{c}0.010^{* *} \\
(2.46)\end{array}$ & $\begin{array}{l}0.046^{*} \\
(1.75)\end{array}$ \\
\hline$\Delta G$ & $\begin{array}{c}-0.276^{* *} \\
(-4.14)\end{array}$ & $\begin{array}{c}-0.189^{* *} \\
(-2.02)\end{array}$ & $\begin{array}{c}-0.274^{* *} \\
(-4.15)\end{array}$ & $\begin{array}{c}-0.186^{* *} \\
(-1.99) \\
\end{array}$ & $\begin{array}{c}-0.290^{* *} \\
(-4.39)\end{array}$ & $\begin{array}{c}-0.214^{* *} \\
(-2.37)\end{array}$ & $\begin{array}{c}-0.285^{* *} \\
(-4.33)\end{array}$ & $\begin{array}{c}-0.208^{* *} \\
(-2.27)\end{array}$ & $\begin{array}{c}-0.287^{* *} \\
(-4.40)\end{array}$ & $\begin{array}{c}-0.218^{* *} \\
(-2.37)\end{array}$ \\
\hline Obs & 1165 & 1165 & 1165 & 1165 & 1165 & 1165 & 1165 & 1165 & 1165 & 1165 \\
\hline$N$ & 15 & 15 & 15 & 15 & 15 & 15 & 15 & 15 & 15 & 15 \\
\hline$T$ & 78 & 78 & 78 & 78 & 78 & 78 & 78 & 78 & 78 & 78 \\
\hline RMSE & 0.0395 & 0.0283 & 0.0392 & 0.0283 & 0.0400 & 0.0285 & 0.0399 & 0.0285 & 0.0399 & 0.0285 \\
\hline
\end{tabular}

Notes: DK FE denotes the Driscoll and Kraay's (1998) Fixed Effects estimator and the CCEMG denotes the Pesaran's (2006) Common Correlated Effects Mean Group estimator. t-statistics in parentheses. RMSE refers to the root mean squared error. ${ }^{*}$ and ${ }^{* *}$ denotes significance at the $10 \%$ and $5 \%$ significance levels, respectively. 
Table 6: Lilien's Index and Sectoral Shifts - Impact of Volatility (DK-FE)

\begin{tabular}{|c|c|c|c|c|c|c|c|c|c|c|}
\hline & (1) & (2) & (3) & (4) & (5) & (6) & (7) & (8) & (9) & (10) \\
\hline$U_{\text {Lagged }}$ & $\begin{array}{c}0.970^{* *} \\
(100.78)\end{array}$ & $\begin{array}{c}0.977^{\text {** }} \\
(101.96)\end{array}$ & $\begin{array}{c}0.984^{* *} \\
(108.69)\end{array}$ & $\begin{array}{l}0.966^{* *} \\
(92.77)\end{array}$ & $\begin{array}{c}0.974^{* *} \\
(118.46)\end{array}$ & $\begin{array}{c}0.968^{* *} \\
(114.59)\end{array}$ & $\begin{array}{c}0.974^{* *} \\
(115.21)\end{array}$ & $\begin{array}{c}0.978^{* *} \\
(113.89)\end{array}$ & $\begin{array}{c}0.965^{\star *} \\
(103.19)\end{array}$ & $\begin{array}{c}0.969^{* *} \\
(108.39)\end{array}$ \\
\hline$\sigma^{p}$ & $\begin{array}{l}1.280^{* *} \\
(2.66)\end{array}$ & $\begin{array}{l}1.164^{* *} \\
(2.30)\end{array}$ & $\begin{array}{l}1.192^{* *} \\
(2.17)\end{array}$ & $\begin{array}{l}1.115^{* *} \\
(2.24)\end{array}$ & $\begin{array}{l}1.356^{* *} \\
(2.77)\end{array}$ & $\begin{array}{l}1.450^{* *} \\
(3.09)\end{array}$ & $\begin{array}{l}1.306^{* *} \\
(2.68)\end{array}$ & $\begin{array}{l}1.212^{* *} \\
(2.45)\end{array}$ & $\begin{array}{l}1.233^{* * *} \\
(2.48)\end{array}$ & $\begin{array}{l}1.422^{* *} \\
(2.94)\end{array}$ \\
\hline$E P U^{e u}$ & $\begin{array}{c}0.024^{* *} \\
(3.78)\end{array}$ & & & & $\begin{array}{l}0.019^{*} \\
(1.86)\end{array}$ & $\begin{array}{l}0.024^{* *} \\
(4.30)\end{array}$ & & & & $\begin{array}{l}0.022^{* *} \\
(2.69)\end{array}$ \\
\hline$E P U^{u s}$ & & $\begin{array}{l}0.034^{* *} \\
(3.87)\end{array}$ & & & & & $\begin{array}{c}0.028^{* *} \\
(4.63)\end{array}$ & & & \\
\hline$V O L^{e u}$ & & & $\begin{array}{l}0.031^{* *} \\
(4.68)\end{array}$ & & $\begin{array}{l}0.021^{\text {** }} \\
(2.20)\end{array}$ & & & $\begin{array}{c}0.015^{* *} \\
(2.36)\end{array}$ & & $\begin{array}{l}0.003 \\
(0.43)\end{array}$ \\
\hline STOCK ${ }^{e u}$ & & & & $\begin{array}{l}-0.026^{* *} \\
(-5.30)\end{array}$ & & & & & $\begin{array}{l}-0.020^{* *} \\
(-3.75)\end{array}$ & \\
\hline$\triangle G D P$ & $\begin{array}{c}-1.060^{* *} \\
(-3.92)\end{array}$ & $\begin{array}{l}-0.964^{* *} \\
(-4.62)\end{array}$ & $\begin{array}{l}-1.096^{\text {** }} \\
(-5.43)\end{array}$ & $\begin{array}{c}-1.203^{* *} \\
(-5.10)\end{array}$ & $\begin{array}{c}-1.003^{* *} \\
(-4.49)\end{array}$ & $\begin{array}{c}-0.875^{* *} \\
(-4.98)\end{array}$ & $\begin{array}{l}-0.818^{* *} \\
(-5.22)\end{array}$ & $\begin{array}{c}-0.852^{* *} \\
(-5.05)\end{array}$ & $\begin{array}{c}-1.019^{* *} \\
(-5.84)\end{array}$ & $\begin{array}{l}-0.788^{* *} \\
(-4.58)\end{array}$ \\
\hline$\Delta I R$ & & & & & & $\begin{array}{l}-0.014^{* *} \\
(-2.66)\end{array}$ & $\begin{array}{l}-0.015^{\text {** }} \\
(-2.80)\end{array}$ & $\begin{array}{l}-0.026^{* *} \\
(-4.25)\end{array}$ & $\begin{array}{l}-0.014^{* *} \\
(-2.38)\end{array}$ & $\begin{array}{l}-0.022^{* *} \\
(-4.21)\end{array}$ \\
\hline$H$ & & & & & & $\begin{array}{l}0.014^{* *} \\
(3.52)\end{array}$ & $\begin{array}{l}0.011^{* *} \\
(3.14)\end{array}$ & $\begin{array}{l}0.006 \\
(0.83)\end{array}$ & $\begin{array}{l}0.009^{* *} \\
(2.30)\end{array}$ & $\begin{array}{l}0.013^{* *} \\
(2.12)\end{array}$ \\
\hline$\Delta G$ & & & & & & $\begin{array}{l}-0.227^{\text {** }} \\
(-3.99)\end{array}$ & $\begin{array}{c}-0.222^{* *} \\
(-4.10)\end{array}$ & $\begin{array}{c}-0.285^{* *} \\
(-4.56)\end{array}$ & $\begin{array}{c}-0.277^{\text {** }} \\
(-4.40)\end{array}$ & $\begin{array}{c}-0.235^{* *} \\
(-4.44)\end{array}$ \\
\hline Obs & 1165 & 1165 & 967 & 1165 & 967 & 1165 & 1165 & 967 & 1165 & 967 \\
\hline$N$ & 15 & 15 & 15 & 15 & 15 & 15 & 15 & 15 & 15 & 15 \\
\hline$T$ & 78 & 78 & 65 & 78 & 65 & 78 & 78 & 65 & 78 & 65 \\
\hline RMSE & 0.0410 & 0.0403 & 0.0418 & 0.0413 & 0.0418 & 0.0395 & 0.0391 & 0.0407 & 0.0400 & 0.0407 \\
\hline
\end{tabular}

Notes: DK FE denotes the Driscoll and Kraay's (1998) Fixed Effects estimator. t-statistics in parentheses. RMSE refers to the root mean squared error. ${ }^{*}$ and ${ }^{* *}$ denotes significance at the $10 \%$ and $5 \%$ significance levels, respectively. 
Table 7: Lilien's Index and Sectoral Shifts - Impact of Volatility (CCEMG)

\begin{tabular}{|c|c|c|c|c|c|c|c|c|c|c|}
\hline & (1) & (2) & (3) & (4) & (5) & (6) & (7) & $(8)$ & (9) & (10) \\
\hline$U_{\text {Lagged }}$ & $\begin{array}{l}0.959^{* *} \\
(57.89)\end{array}$ & $\begin{array}{l}0.947^{\star *} \\
(48.14)\end{array}$ & $\begin{array}{l}0.941^{* *} \\
(37.91)\end{array}$ & $\begin{array}{l}0.952^{* *} \\
(48.77)\end{array}$ & $\begin{array}{l}0.942^{* *} \\
(38.64)\end{array}$ & $\begin{array}{l}0.940^{* *} \\
(43.88)\end{array}$ & $\begin{array}{l}0.926^{* *} \\
(40.14)\end{array}$ & $\begin{array}{l}0.922^{* *} \\
(33.43)\end{array}$ & $\begin{array}{l}0.936^{* *} \\
(46.95)\end{array}$ & $\begin{array}{l}0.923^{\text {** }} \\
(32.21)\end{array}$ \\
\hline$\sigma^{p}$ & $\begin{array}{c}0.668^{*} \\
(1.87)\end{array}$ & $\begin{array}{l}0.660^{*} \\
(1.88)\end{array}$ & $\begin{array}{l}1.070^{* *} \\
(2.10)\end{array}$ & $\begin{array}{l}0.570 \\
(1.63)\end{array}$ & $\begin{array}{l}1.067^{*} \\
(1.94)\end{array}$ & $\begin{array}{l}0.707^{\text {** }} \\
(2.36)\end{array}$ & $\begin{array}{l}0.754^{\text {** }} \\
(2.59)\end{array}$ & $\begin{array}{l}1.301^{\text {** }} \\
(2.31)\end{array}$ & $\begin{array}{l}0.634^{\text {** }} \\
(2.41)\end{array}$ & $\begin{array}{c}1.372^{* *} \\
(2.43)\end{array}$ \\
\hline EPU $U^{e u}$ & $\begin{array}{l}0.003 \\
(0.33)\end{array}$ & & & & $\begin{array}{l}0.004 \\
(0.52)\end{array}$ & $\begin{array}{l}-0.001 \\
(-0.14)\end{array}$ & & & & $\begin{array}{l}0.001 \\
(0.07)\end{array}$ \\
\hline$E P U^{u s}$ & & $\begin{array}{l}-0.004 \\
(-0.46)\end{array}$ & & & & & $\begin{array}{l}-0.008 \\
(-0.97)\end{array}$ & & & \\
\hline$V O L^{e u}$ & & & $\begin{array}{l}-0.004 \\
(-0.47)\end{array}$ & & $\begin{array}{l}-0.006 \\
(-0.81)\end{array}$ & & & $\begin{array}{l}-0.005 \\
(-0.50)\end{array}$ & & $\begin{array}{l}-0.005 \\
(-0.61)\end{array}$ \\
\hline STOCKeu & & & & $\begin{array}{l}-0.024 \\
(-1.41)\end{array}$ & & & & & $\begin{array}{c}-0.030^{*} \\
(-1.71)\end{array}$ & \\
\hline$\triangle G D P$ & $\begin{array}{c}-0.747^{* *} \\
(-3.67)\end{array}$ & $\begin{array}{c}-0.653^{* *} \\
(-3.19)\end{array}$ & $\begin{array}{c}-0.795^{* *} \\
(-2.93)\end{array}$ & $\begin{array}{c}-0.707^{\star *} \\
(-2.89)\end{array}$ & $\begin{array}{c}-0.810^{* *} \\
(-2.95)\end{array}$ & $\begin{array}{c}-0.594^{* *} \\
(-3.24)\end{array}$ & $\begin{array}{c}-0.509^{* *} \\
(-2.86)\end{array}$ & $\begin{array}{c}-0.619^{* *} \\
(-2.24)\end{array}$ & $\begin{array}{c}-0.612^{* *} \\
(-2.35)\end{array}$ & $\begin{array}{c}-0.663^{* *} \\
(-2.37)\end{array}$ \\
\hline$\Delta I R$ & & & & & & $\begin{array}{l}-0.042 \\
(-1.49)\end{array}$ & $\begin{array}{l}-0.043 \\
(-1.48)\end{array}$ & $\begin{array}{l}-0.025 \\
(-0.64)\end{array}$ & $\begin{array}{l}-0.048 \\
(-1.46)\end{array}$ & $\begin{array}{l}-0.024 \\
(-0.62)\end{array}$ \\
\hline$H$ & & & & & & $\begin{array}{l}0.043^{*} \\
(1.79)\end{array}$ & $\begin{array}{l}0.046^{*} \\
(1.72)\end{array}$ & $\begin{array}{l}0.082^{\text {** }} \\
(3.07)\end{array}$ & $\begin{array}{l}0.041^{* *} \\
(2.14)\end{array}$ & $\begin{array}{c}0.088^{* *} \\
(3.13)\end{array}$ \\
\hline$\Delta G$ & & & & & & $\begin{array}{c}-0.183^{\text {** }} \\
(-2.09)\end{array}$ & $\begin{array}{c}-0.219^{\text {** }} \\
(-2.62)\end{array}$ & $\begin{array}{l}-0.147 \\
(-1.35)\end{array}$ & $\begin{array}{c}-0.186^{\text {** }} \\
(-2.05)\end{array}$ & $\begin{array}{l}-0.144 \\
(-1.38)\end{array}$ \\
\hline Obs & 1165 & 1165 & 967 & 1165 & 967 & 1165 & 1165 & 967 & 1165 & 967 \\
\hline$N$ & 15 & 15 & 15 & 15 & 15 & 15 & 15 & 15 & 15 & 15 \\
\hline$T$ & 78 & 78 & 64 & 78 & 64 & 78 & 78 & 64 & 78 & 64 \\
\hline RMSE & 0.0305 & 0.0305 & 0.0313 & 0.0301 & 0.0308 & 0.0278 & 0.0278 & 0.0280 & 0.0274 & 0.0275 \\
\hline
\end{tabular}

Notes: CCEMG denotes the Pesaran's (2006) Common Correlated Effects Mean Group estimator. t-statistics in parentheses. RMSE refers to the root mean squared error. ${ }^{*}$ and ${ }^{* *}$ denotes significance at the $10 \%$ and $5 \%$ significance levels, respectively. 